\title{
Os gêneros Zanthoxylum L. e Esenbeckia Kunth (Rutaceae) no Estado de Pernambuco, Brasil ${ }^{1}$
}

\author{
Maria de Fátima Figueiredo Melo ${ }^{2,4}$ e Carmen Sílvia Zickel ${ }^{3}$
}

Recebido em 20/04/2001. Aceito em 01/07/2003

\begin{abstract}
RESUMO - (Os gêneros Zanthoxylum L. e Esenbeckia Kunth (Rutaceae) no Estado Pernambuco, Brasil). Este trabalho consiste no levantamento das espécies dos gêneros Zanthoxylum e Esenbeckia ocorrentes em Pernambuco. Foi baseado nos caracteres morfológicos das espécies obtidas em campo e nos materiais de 16 herbários brasileiros. Foram registradas nove espécies de Zanthoxylum: Z. caribaeum Lam., Z. fagara (L.) Sarg., Z. gardneri Engl., Z. hamadryadicum Pirani, Z. monogynum A. St.-Hil., Z. petiolare A. St.-Hil \& Tul., Z. rhoifolium Lam., Z. stelligerum Turcz. e Z. syncarpum Tul. Para Esenbeckia foram verificadas cinco espécies: E. almawillia Kaastra, E. febrifuga (A. St.-Hil.) Juss. ex Mart., E. garandiflora Mart., E. leiocarpa Engl. e E. pilocarpoides Kunth. Para reconhecimento das espécies são apresentadas chaves de identificação, descrições, ilustrações, distribuição geográfica, comentários e nomes vulgares.
\end{abstract}

Palavras-chaves: Zanthoxylum, Esenbeckia, Rutaceae, taxonomia, Pernambuco

\begin{abstract}
The genera Zanthoxylum L. and Esenbeckia Kunth (Rutaceae) in the State of Pernambuco, Brazil). This work is a survey of the species of Zanthoxylum and Esenbeckia occuring in the State of Pernambuco. It was based on morphological characters of the species obtained during field trips and of specimens from 16 Brazilian herbaria. Nine species were recorded for Zanthoxylum: Z. caribaeum Lam., Z. fagara (L.) Sarg., Z. gardneri Engl., Z. hamadryadicum Pirani, Z. monogynum A. St.-Hil., Z. petiolare A. St.-Hil \& Tul., Z. rhoifolium Lam., Z. stelligerum Turcz., and Z. syncarpum Tul. Esenbeckia comprised five species: E. almawillia Kaastra, E. febrifuga (A. St.-Hil.) Juss. ex Mart., E. grandiflora Mart., E. leiocarpa Engl., and E. pilocarpoides Kunth. Identication keys, descriptions, ilustrations, geographic distribution, common names, and comments on the species are presented.
\end{abstract}

Key words: Zanthoxylum, Esenbeckia, Rutaceae, taxonomy, Pernambuco

\section{Introdução}

Os gêneros da família Rutaceae Juss. estão amplamente distribuídos nas regiões tropicais, subtropicais e temperadas do mundo, com aproximadamente 1.600 espécies, com grande ocorrência na Austrália e África. No Brasil, a família está representada por cerca de 29 gêneros e 182 espécies (Barroso et al. 1986).

Zanthoxylum s.l. (incluindo Fagara) compreende aproximadamente 200 espécies lenhosas com perianto mono ou diclamídeo, arbustivas ou arbóreas, pantropicais, com poucas espécies estendendo-se nas zonas temperadas da América do Norte e leste da Ásia.

Há problema na conceituação entre Zanthoxylum L. e Fagara L. Essa conceituação foi discutida por muitos autores, desde a época lineana, quando trataram Zanthoxylum como gênero distinto de Fagara. Nessa época, as diferenças baseavam-se no perianto monoclamídeo, no primeiro gênero, e diclamídeo, no segundo. Contudo, para as espécies monoclamídeas, a polêmica baseava-se na estrutura do perianto, se sépala ou pétala. Assim, o arranjo dos verticilos do perianto foi para Engler (1931) e Reeder \& Cheo (1951) um caráter relevante para separar Zanthoxylum de Fagara. A ocorrência de espécies que exibem estrutura intermediária entre Zanthoxylum e Fagara foi mencionada por Hartley (1966) e Brizicky (1962), que consideraram Zanthoxylum uma condição derivada do tipo Fagara por aborto de algumas ou todas as sépalas.

As espécies brasileiras de Zanthoxylum apresentam perianto diclamídeo, enquanto os espécimes de regiões temperadas da América Central e leste da Ásia apresentam perianto mono e diclamídeo. Apesar de muitos trabalhos sugerirem a fusão dos dois gêneros, outros estudos baseados nos

\footnotetext{
1 Parte da Dissertação de Mestrado da primeira Autora, PPGB/UFRPE

2 INPA, Departamento de Botânica, Av. André Araújo, 2936, CEP 69083-000, Manaus, AM, Brasil

3 Universidade Federal Rural de Pernambuco, Departamento de Biologia/Botânica, Av. Dom Manuel de Medeiros, s/n, Dois Irmãos, CEP 52171-900, Recife, PE, Brasil (zickebr@yahoo.com)

4 Autor para correspondência: (ffmelo@inpe.gov.br)
} 
aspectos morfológicos das estruturas do perianto (Engler 1874, 1931; Bentham \& Hooker 1862; Reeder \& Cheo 1951; Escalante 1961; Spichiger \& Ortega 1987) preferem considerar Fagara como um gênero separado, como subgênero ou seção de Zanthoxylum. Fish \& Watterman (1973) e Watterman (1975), em análises de evidências quimiossistemáticas dos metabólitos secundários, e Guerra (1987), utilizando a estrutura nuclear como parâmetro taxonômico, sugerem que os dois gêneros podem ser fusionados devido à forte semelhança.

A controvérsia dessa delimitação, especialmente relacionada às estruturas do perianto, levou Beurton (1994) a fazer análise detalhada da morfologia floral de Zanthoxylum s.l., concluindo que a condição de perianto unisseriado de Zanthoxylum s.s. surgiu polifileticamente a partir da condição bisseriada e, portanto, esses táxons podem ser considerados como um gênero único, como comprovadas nas espécies intermediárias observadas por Brizicky (1962) e Hartley (1966).

Diante da polêmica sobre a delimitação do gênero adota-se, no presente trabalho, Zanthoxylum como gênero válido e Fagara como sinônimo, frente aos vários trabalhos que abordam os diferentes aspectos morfológicos, citotaxonômicos, fitoquímicos que oferecem essa indicação.

O estudo do gênero Esenbeckia mostra que existe estreita relação com Metrodorea. Segundo Pirani (1999), esses gêneros apresentam semelhanças florais e do lenho, por isso os espécimes costumam ser confundidos e identificados erroneamente. A obra mais importante com tratamento sistemático foi realizada por Kaastra (1982) para tribo Pilocarpinae.

Poucos levantamentos têm sido realizados para a flora local, citando-se Zanthoxylum em listas florísticas como as de Sales et al. (1998), Ferraz et al. (1998), Tavares et al. (2000) para diferentes ambientes de floresta serrana e vegetação de caatinga. Entretanto, Esenbeckia, até o presente, não foi mencionado em listas florísticas. Esse gênero, apesar de ser pouco freqüente na flora de Pernambuco, necessitava de estudo, uma vez que parte do material encontrava-se sem identificação nos herbários.

Portanto, este trabalho tem como objetivo o estudo taxonômico dos gêneros Zanthoxylum e Esenbeckia no Estado de Pernambuco, com dados atualizados da distribuição geográfica, chaves de identificação e ilustrações dos principais caracteres morfológicos para identificação dos táxons, além de fornecer novas informações para flora local.

\section{Material e métodos}

O Estado de Pernambuco situa-se na região Nordeste do Brasil, entre $7^{\circ} 15^{\prime} 4^{\prime \prime} S$ a $9^{\circ} 28^{\prime} 6$ ' $S$ e de $34^{\circ} 48^{\prime} 35^{\prime \prime} \mathrm{W}$ a $41^{\circ} 19^{\prime} 54^{\prime \prime} \mathrm{W}$, apresentando maior extensão territorial no sentido de leste para oeste (Andrade-Lima 1960). A área territorial é de aproximadamente $98.281 \mathrm{~km}^{2}$.

A elaboração deste estudo foi baseada em análise morfológica de espécimes coletados no Estado de Pernambuco e material herborizado proveniente de vários herbários do Brasil. Para obtenção de amostras das plantas vivas foram realizadas excursões a várias localidades do Estado, no período de setembro/1998 a junho/1999, abrangendo 69 municípios situados em diferentes zonas fitogeográficas, além de dois municípios na Bahia, um em Alagoas e um no Piauí.

Parte do material estudado foi proveniente dos herbários nacionais: ALCB, CEN, CEPEC, EAC, EAN, IPA, JPB, MBML, PEUFR, SP, TEGB, UB, UEC, UFP, UFS (Holmgren et al. 1990) e Herbário Sérgio Tavares (HST), da Universidade Federal Rural de Pernambuco.

A identificação do material foi realizada com base nos trabalhos de Cowan \& Smith (1973), Albuquerque (1976) e Engler (1874; 1931), utilizando-se os sinônimos mais recentes e o conceito de Pirani (1999) para Zanthoxylum. O gênero Esenbeckia foi baseado na revisão de Kaastra (1982). Além da bibliografia consultada, a análise baseou-se no estudo morfológico dos exemplares, comparando-se, quando possível, com diagnoses originais, além de chaves de identificações e informações de trabalhos atualizados.

Para a descrição das estruturas dos táxons foi utilizada, para venação, a nomenclatura proposta nos trabalhos de Hickey (1973), para indumento, Lawrence (1951) e nos demais aspectos Radford et al. (1974). A abreviação dos autores dos nomes científicos foi baseada em Brummit \& Powell (1992). As informações sobre a coloração das flores e frutos, hábitat, hábito, fenologia e distribuição geográfica foram baseadas principalmente nas observações das espécies no campo e nas etiquetas das exsicatas.

\section{Resultados e discussão}

\section{Zanthoxylum L.}

Árvores, arbustos ou arvoretas, geralmente dióicos, raramente polígamo-dióicos, as arbóreas apresentam copa frondosa, alcançando até $20 \mathrm{~m}$ alt., troncos e ramos aculeados, raramente não aculeados, ocasionalmente 
com acúleos na face inferior dos folíolos; acúleos com grande variação intra-específica, longos ou curtos, eretos ou recurvados, com ou sem tricomas; tricomas simples e/ou estrelados, densos a esparsos nos ramos, folhas e elementos florais, com coloração esbranquiçada ou translúcida na maioria das espécies, ferrugínea em Z. rhoifolium e Z. stelligerum. Folhas alternas, compostas, paripinadas ou imparipinadas, com até 15 pares de folíolos, raramente uni ou trifolioladas, margem geralmente crenada, variando de crenulada até quase inteira, com glândulas oleíferas entre as crenas ou por toda a lâmina foliar; é freqüente a presença de domácias presentes na face inferior do folíolo, principalmente na base de algumas espécies. Inflorescências terminais, axilares ou laterais, variando de tirsos, panículas piramidais, corimbos, racemos a espigas (Porter \& Elias 1979; Hartley 1966; Pirani 1999), a maioria apresentando panículas, raramente racemos (Fig. 40), geralmente multifloras; bráctea 1 por inflorescência, raramente ausente, ovais com ápice acuminado, exceto em $Z$. hamadryadicum que apresenta bráctea linear a lanceolada (Fig. 18); bractéolas 1-4. Flores pequenas, actinomorfas, unissexuais, raramente bissexuais, geralmente brancas a esverdeadas; sépalas 3-5, livres ou concrescidas na base, geralmente ovais com ápice acuminado ou triangulares, geralmente persistentes no fruto, glabras ou pubérulas, em algumas espécies com indumento na face externa; pétalas 3-5, livres, côncavas e imbricadas, geralmente glabras, podendo apresentar tricomas na face externa; flores masculinas com pistilódios (Fig. 37) em número variado, geralmente de 1-3(-5), livres ou conados, ovóides a cônicos, com estigma diferenciado; estames 3-5, livres, inseridos na base do disco, geralmente exsertos na ântese, filetes subulados e glabros, anteras dorsifixas, geralmente ovais, bitecas, com deiscência rimosa; disco em forma de anel, glabro (Pirani 1999); flores femininas possuem carpelos sobre o ginóforo; estames rudimentares inseridos na base do ginóforo (Beurton 1994) ou ausentes; carpelos 1-5, acróstilos, anacróstilos e anacróstilos-basistilos, curtos e estipitados, exceto em Z. fagara (Beurton 1994), são livres ou conados pelo ou estigma (Fig. 32), raramente conados axial e lateralmente por $3 / 4$ do seu comprimento (Fig. 44), estilete ereto ou encurvado; estigma capitado (Fig. 13) a discóide (Fig. 43). Fruto folículo ou esquizocarpo, raramente cápsula (Fig. 44), geralmente com superfície glandular, raramente muricada. Semente 1, ovóide a globosa, freqüentemente suspensa pelo funículo longo na maturação (Fig. 35); testa preta, brilhante; hilo circular a alongado-linear (Fig. 45), comumente triangular-alongado em direção ao ápice da semente (Tiffney 1980).

O gênero Zanthoxylum apresenta cerca de 200 espécies, principalmente pantropicais e cerca de 15 espécies ocorrendo dentro de zonas temperadas da América do Norte e leste da Ásia (Beurton 1994).

Chave para a identificação das espécies de Zanthoxylum em Pernambuco

1. Folhas com até 5 folíolos

5. Z. monogynum

1. Folhas com mais de 5 folíolos

2. Inflorescências em racemos ou espigas

3. Folhas com até 7 folíolos; tricomas hirsutos em ambas as faces; frutos cápsulas

9. Z. syncarpum

3. Folhas com 7-17 folíolos; frutos folículos

4. Folíolos curtos até $1,8 \mathrm{~cm}$ compr., dispostos nas terminações dos ramos, oblongos, margem revoluta, indumento estrelado em ambas as faces; flores com pétalas lineares a oblongas, pilosas

4. Z. hamadryadicum

4. Folíolos 1,2-4,5cm compr., não dispostos nas terminações dos ramos, elípticos a obovais, margem crenada, glabros a pubérulo; flores com pétalas glabras, elípticas a ovais

2. Z. fagara

2. Inflorescências em panículas

5. Folíolos com um par de domácias na base; inflorescência suberosa 1. Z. caribaeum

5. Folíolos sem domácias; inflorescência não suberosa

6. Folíolos glabros

7. Folíolos com base atenuada, ápice acuminado, raramente retuso

3. Z. gardneri

7. Folíolos com base oblíqua, geralmente falcada, ápice cuspidado

6. Z. petiolare

6. Folíolos com indumento estrelado, raramente simples 
8. Folíolos densamente estrelados na face inferior, base obtusa a arredondada; frutos sub-globosos com superfície glandular pouco saliente; sementes elipsóides, funículo curto na maturação .....

8. Z. stelligerum

8. Folíolos esparsamente estrelados na face inferior, base oblíqua; frutos globosos, superfície glandular saliente; sementes esféricas, funículo longo na maturação

7. Z. rhoifolium

1.1 Zanthoxylum caribaeum Lam., Encycl. 2: 39. 1786. Fig. 1-5

Nomes vulgares: espinho-de-barrão (PE), espinhocheiroso (BA), espinheiro-preto (CE).

Arbustos ou árvores, 5-9m alt. Ramos castanhoclaros a castanho-acinzentados, glabros, com acúleos retos ou levemente recurvados para cima ou para baixo, glabros. Folhas 5-27,3cm compr., imparipinadas ou paripinadas, raques com 3-7 pares de folíolos, aculeadas, glabras; pecíolos cilíndricos, 2,2-4,8cm compr.; folíolos 2-11,5×1,3-4,9cm, (sub)opostos, peciolulados, oblongos, elípticos a obovados, base aguda, atenuada, raramente oblíqua, com 1 par de domácias revolutas, ápice acuminado, margem crenada, glabros, cartáceos, face superior com nervura principal impressa, face inferior com nervura principal proeminente. Panículas $3-4 \mathrm{~cm}$ compr., terminais, suberosas, com fendas transversais, formando muitos retângulos enrugados, espessas, glabras; bráctea ca. $1,1 \times 1,1 \mathrm{~mm}$ compr., côncava, carnosa, glabra; bractéolas 4, ca. 1,2×1,2mm, largo-ovais, ápice acuminado, rosuladas, carnosas, glabras. Flores masculinas 3-4mm compr.; sépalas 5, lacínios ca. $1,5 \times 1,5 \mathrm{~mm}$, suborbiculares, ápice obtuso, carnosos, imbricados; pétalas 5, 2,8-3,0×1,2-1,8mm, oblongas, elípticas, carnosas, imbricadas, glabras; estames 5 , 2,0-2,4mm compr., menores que as pétalas, filetes 1,2-1,5mm compr., subulados, glabros, anteras 1,8-2,0mm compr., ovais a oblongas; pistilódio $0,8-0,9 \mathrm{~mm}$ diâm. e ca. 0,2mm alt., 5-lobado. Flores femininas semelhantes às masculinas; carpelos 5 , conados no estigma, glabros. Folículos 4,0-4,5mm diâm., obovados, sub-globosos, superfície enrugada, glandular; semente ca. $3 \mathrm{~mm}$ diâm., ovóide, hilo arredondado, preta e brilhante.

Material examinado: BRASIL. Pernambuco: Buenos Aires, V/1999, bot., Melo 236 (PEUFR); São Lourenço da Mata, X/1983, bot., Chiappeta 397 (UFP; IPA); Tapera, I/1926, fl., Pickel 1226 (IPA); São Benedito do Sul, I/1999, fl., Melo 165 (PEUFR); Vitória de Santo Antão, IX/1999, bot., Melo et al. 248 (PEUFR).

Z. caribaeum distingue-se das demais espécies pela panícula suberosa, com superfície espessa, enrugada, glabra e folíolos com um par de domácias na base da face inferior da lâmina foliar.

Z. rugosum A. St.-Hil. e Z. chiloperone Mart. ex Engl. foram listadas nos levantamentos realizados nos principais herbários de Pernambuco. Contudo, foram sinonimizadas recentemente por Pirani (1999) sob Z. caribaeum Lam.

Esta espécie possui distribuição nas Antilhas, Barbados, Costa Rica, Guadalupe, Martinica, Panamá, Porto Rico e Nordeste da América do Sul, Argentina e Paraguai (Wilson 1911). Ocorre em todos os Estados do Brasil, em florestas úmidas a mesófilas e semi-áridas (Pirani 1999). Em Pernambuco, está distribuída nas Zonas da Mata e Agreste (Buenos Aires, São Lourenço da Mata, São Benedito do Sul, Vitória de Santo Antão), sendo encontrada em vegetação menos densa, em campos abertos ou no interior de matas, em áreas de clareiras, com solo areno-argiloso. Apresenta caducifolia, mesmo em áreas com precipitação média anual de $800-1.000 \mathrm{~mm}$.

1.2 Zanthoxylum fagara (L.) Sarg., Garden \& Forest 3: 186.1890.

Schinus fagara L., Sp. pl. 1: 389. 1753.

Fig. 6-10.

Nomes vulgares: limãozinho (PE), mamica-deporca (São Paulo), coentrão (PB), mapurito (Venezuela), colima (Texas), limoncillo (Cuba), xic-ché (Yucatan), una-de-gato (Colômbia), espino-rubial (Porto Rico).

Árvores ou arvoretas ca. $6 \mathrm{~m}$ alt. Ramos acinzentados a castanhos, glabros, com ou sem acúleos pontiagudos, geralmente recurvados para baixo. Folhas 2,5-11,2cm compr., imparipinadas, raques levemente aladas, com 3-5 pares de folíolos, canaliculadas, glabras; pecíolos 0,6-2,7cm compr., semicilíndricos, canaliculados na face superior; folíolos basais $0,9-3,5 \times 0,5-2 \mathrm{~cm}$, apicais 1,2-4,5×0,6-2,3cm, (sub)opostos, sub-sésseis, obovados a elípticos, base oblíqua, cuneada, com 1-2 domácias na base dos folíolos basais e apicais, geralmente ausentes nos demais, ápice obtuso, retuso, margem crenada, glabros, membranáceos a cartáceos. Espigas ou racemos até $6,5 \mathrm{~cm}$ compr., terminais ou axilares, paucifloras, pubérulas, com estrias longitudinais; bráctea ca. $1 \mathrm{~mm}$ de compr., oval, glabra; bractéola ca. 1,1-1,8mm compr., 
oval, glabra. Botões florais masculinos ca. 1,8-5,5mm compr., subglobosos, (sub)sésseis; sépalas 4, lacínios menores 0,6-1,5×1-1,2mm, ovais, lacínios maiores, 1-1,9×1,8-2mm, deltóides, glabros, raramente pubérulos; pétalas 4, 1,9-3,8×1-2mm, côncavas, elípticas a ovais, glabras; estames 4 , com 1-5mm compr., inseridos sob disco lobado, filetes $0,6-5,0 \mathrm{~mm}$ compr., subulados, anteras 0,9-1,8mm compr., ovais; pistilódio 1, 0,9-2,0mm compr. Flores femininas não observadas. Folículos 5-7× 3,5-4,8mm na maturação, sub-globosos; semente 1 , 2,3-3,9×2,0-3,4mm, esférica, hilo arredondado, preta, lisa e brilhante.

Material selecionado: BRASIL. Pernambuco: Águas Belas, XI/1969, fr., Andrade-Lima 69-625 (IPA); Brejo da Madre de Deus, VI/1999, fr., Silva 76 (PEUFR); Brejo da Madre de Deus, X/1999, fl. e bot., Silva 168 (PEUFR); Brejo da Madre de Deus, VIII/1998, fr. Silva 10 (PEUFR); Caruaru, VII/1994, fr., Sales 229 (PEUFR); Caruaru, V/1994, fr., Borges \& Araújo 13 (PEUFR); Garanhuns, XI/1998, bot., Melo 103 (PEUFR).

Distingue-se das demais espécies principalmente por apresentar folíolos obovados a elípticos, membranáceos, glabros, inflorescências em racemos ou espigas e flores tetrâmeras. No campo é facilmente reconhecida por ser arvoreta com copa rala, irregular, tronco densamente aculeado e quando os ramos são cortados exalam um aroma forte e desagradável (terebentina). Z. hiemale A. St.-Hil., foi recentemente sinonimizado por Pirani (1999) sob Z. fagara (L.) Sarg.

Ocorre desde a América do Norte até a América do Sul, dos Estados Unidos (Flórida e Texas), sul do México e regiões caribenhas até o Peru e nordeste da Argentina (Porter \& Elias 1979). De acordo com Pirani (1999), essa espécie tem ampla distribuição no Brasil (Bahia, Mato Grosso do Sul, Rio de Janeiro, Roraima, e Estados do Sul). Z. fagara ocorre na zona do agreste de Pernambuco (Caruaru, Brejo da Madre de Deus, Garanhuns e Águas Belas), com habitat em bordas e interior de matas, em capoeiras ou terrenos encapoeirados.

1.3 Zanthoxylum gardneri Engl., in Mart., Fl. bras. 12(2): 165. 1874.

Fig. 11-14.

Nomes vulgares: laranjinha, limãozinho (CE), catuaba-de-espinho (MA).

Arbustos, arvoretas ou árvores ca. $8 \mathrm{~m}$ alt. Ramos glabros, sem acúleos, castanho-escuros; Folhas imparipinadas, raramente paripinadas, raques $9,0-10,2 \mathrm{~cm}$ compr., subaladas, 1-3 pares de folíolos, canaliculadas, glabras; pecíolos 3-6cm compr., semicilíndricos; folíolos 3,5-4×1-4,5cm, (sub)opostos, peciolulados, elípticos a oblongo-elípticos, base atenuada, ápice acuminado, raramente retuso, margem inteira, raramente crenada, cartáceos, glabros, nervuras principal e lateral proeminentes em ambos os lados. Panículas terminais e axilares, 5-6cm compr., multifloras, glabras a pubérulas; bráctea ca. $1 \mathrm{~mm}$ compr., glabra; bractéolas 3 , ca. $0,5 \mathrm{~mm}$ compr., ovais, ápice acuminado; pedicelo ca. 1,2mm compr. Flores masculinas 1,8-2,0×1,4mm; sépalas 5, lacínios $0,5 \times 0,6 \mathrm{~mm}$ compr, obovais, membranáceos, glabros; pétalas 5, 2,3×1,1 $\mathrm{mm}$ compr., oblongas, côncavas, glabras, membranáceas; estames 5 , ca. $3,1 \mathrm{~mm}$ compr., exsertos, filetes ca. 2,5mm compr., subulados, glabros, anteras ca. 0,6mm compr., cordiformes, ápice obtuso; pistilódio 1, ca. 1,2mm compr. Flores femininas 3,6-4,0×3,0-3,5mm; sépalas 5, lacínios 1,0-1,4mm compr., triangulares, imbricados, glabros; pétalas 5, 2,8-3,0×1,2-1,4mm, elípticas, glabras; gineceu de 1,7-1,8mm compr., anacróstilo, unicapelar. Folículos $65,5 \times 5,5 \mathrm{~mm}$, sub-globosos, superfície glandular; semente 5,0-5,2mm compr., esférica, hilo arredondado, preta, lisa e brilhante.

Material examinado: BRASIL. Pernambuco: Exu, X/1977, fl., fr., Academia Brasileira de Ciências (IPA 23141).

Durante o período de coleta, Z. gardneri Engl. não foi amostrado nos municípios percorridos no Estado de Pernambuco. Através de levantamentos realizados nos principais herbários locais, apenas uma coleta foi identificada no município de Exu (PE). Dos materiais enviados de outros herbários do Brasil, o mais representativo foi o do Ceará. A falta de mais exemplares em herbários pode indicar falta de coletas, ameaça de extinção ou, provavelmente, pequena representatividade no Estado. A espécie mais próxima é $Z$. monogynum. Contudo, Z. gardneri apresenta maior número de folíolos (3-)5-7(-9), oblongo-elípticos, base atenuada, ápice acuminado. No Brasil, ocorre nos Estados da Bahia, Ceará, Maranhão, Pará, Piauí, principalmente na Chapada do Araripe (sul do Ceará e oeste de Pernambuco). Pirani (1999) comentou que esta espécie está restrita à região nordeste, principalmente nos cerrados e carrascos dentro do domínio das caatingas, mas também em florestas úmidas, até $900 \mathrm{~m}$ de altitude.

1.4 Zanthoxylum hamadryadicum Pirani, Brittonia 45(2): 154, fig. 1.1993.

Fig. 15-20.

Nomes vulgares: ardente, pratudo.

Arbustos ou arvoretas 2-5m alt. Ramos castanhos, 

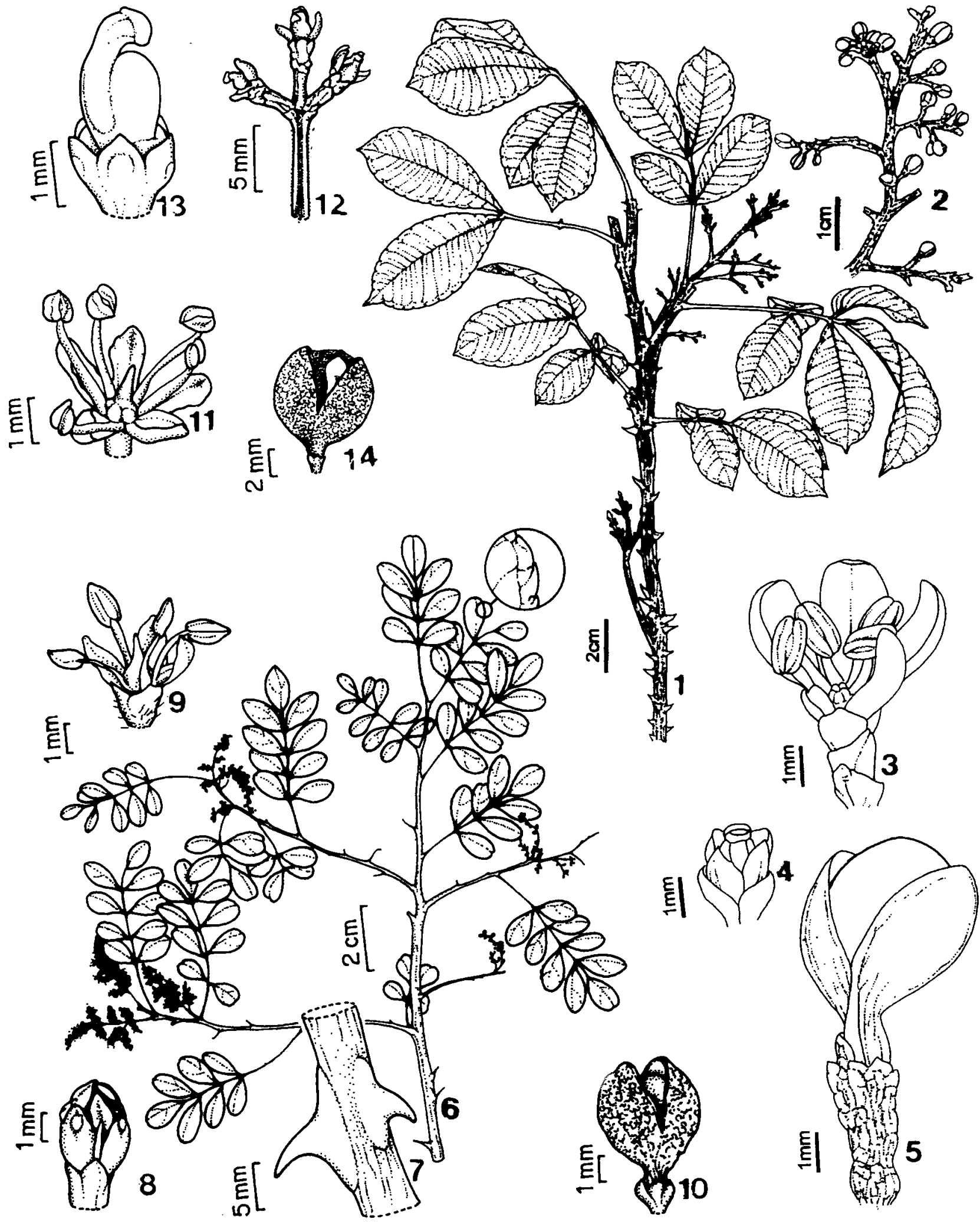

Figuras 1-5. Zanthoxylum caribaeum 1. Hábito. 2. Inflorescência. 3. Flor masculina evidenciando estames e pistilódio (Melo 249 ). 4. Gineceu (Chiappeta 397). 5. Folículo aberto evidenciando semente (Melo 250). Figuras 6-10. Zanthoxylum fagara. 6. Hábito. 7. Detalhe dos acúleos (Silva 168). 8. Detalhe do botão. 9. Flor masculina evidenciando estames e pistilódio (Silva 168). 10. Folículo aberto. Figuras 11-14. Zanthoxylum gardneri. 11. Flor masculina evidenciando estames e pistilódio (Fernandes \& Bezerra s.n. UEC 9505). 12. Ramo da inflorescência. 13. Detalhe do gineceu (Félix \& Miranda s.n. EAN 9052). 14. Folículo evidenciando semente (Salgado 119). 
acinzentados, com gemas protegidas por escamas, recobertas por indumento estrelado e tomentoso, cicatrizes ao longo dos ramos, sem espinhos, glabrescentes. Folhas imparipinadas, dispostas nas terminações dos ramos; raques 3,5-9,5cm compr., levemente aladas com 7-8(-13) pares de folíolos, densas ou esparsamente tomentosas; pecíolos $0,8-1,3 \mathrm{~cm}$ compr., face superior denso a esparsamente tomentosos; folíolos basais $0,3-1,0 \times 0,2-0,6 \mathrm{~cm}$, apicais $0,9-1,8 \times 0,2-0,6 \mathrm{~cm}$ (sub)opostos, sésseis, oblongos, base oblíqua, arredondada, ápice retuso, emarginado, margem revoluta, face superior com tricomas estrelados menores, face inferior recoberta por tricomas maiores, denso-estrelados, membranáceos, discolores. Racemos 1,0-1,7cm compr., 6 a 23 flores; bráctea 1,0,5-1,6mm compr., linear-lanceolada, recoberta por indumento estrelado e simples; pedicelos 0,6-1,0mm compr. Flores masculinas (Lemos 54) com 1,5-2,0mm compr.; sépalas 4, lacínios 1,0-1,5×0,2-0,4mm, lanceolados, esparsamente recobertos por tricomas simples e estrelados; pétalas 4-(-5), 1,0-1,5×0,3-0,5mm, lineares a oblongas, pubescentes ao longo da margem, face externa com indumento simples; estames 4, ca. $1 \mathrm{~mm}$ compr. (em botão), filetes $0,6-1,0 \mathrm{~mm}$ compr., subulados, pubérulos próximos da base, anteras ca. $0,5 \times 0,5 \mathrm{~mm}$, sub-globosas, glabras; pistilódio 1 , 0,6-1,0mm compr., cônico, disco anular, glabro. Flores femininas não observadas. Folículos 2,8-4,0mm diâm., sub-globosos, superfície glandular; semente 2,4-2,6mm diâm., sub-globosa, hilo alongado, preta.

Material examinado: BRASIL. Pernambuco: Afrânio, IV/1971, fl., fr., Heringer et al. 335 (parátipo: PEUFR); Araripina, IV/1983, fr., Chiappeta et al. s.n. (PEUFR 7327); Araripina, II/1999, veg., Melo 194 (PEUFR); Serrolândia, XII/1983, fl., Fotius 3648 (isótipo: IPA).

Pode ser facilmente reconhecida no campo pelo porte arbustivo ou arvoreta, folhas pilosas com folíolos oblongos e curtos, cerca de $1 \mathrm{~cm}$ de compr., inflorescências em racemos curtos de até $2 \mathrm{~cm}$ e flores pequenas e delicadas com 4-5 pétalas e sépalas.

Espécie de distribuição restrita à região Nordeste. Pirani (1999) mencionou apenas seis exemplares examinados em todo o Brasil. Até o presente momento, Z. hamadryadicum é conhecida apenas em Boquira (BA), Chapada do Araripe (CE), Serra da Capivara (PI), em carrasco e campos sujos, formações fechadas, na chapada arenítica e em toda área de caatinga.

1.5 Zanthoxylum monogynum A. St.-Hil., Hist. Pl. remarq. Brésil. 1: 150, t. 19, fig. a. 1824.

Fig. 21-24.
Nomes vulgares: tinguaciba-da-restinga, tinguaciba, limão-bravo, laranjeira-do-mato e limãozinho (Machado 1944).

Arbustos ca. 1,5m alt. Ramos inermes ou com acúleos esparsos, geralmente com regiões de catafilos, castanhos, glabros. Folhas imparipinadas, raques 3,0-7,5cm, com 1-2 pares de folíolos, subaladas; pecíolos 1,3-3,5cm compr., semicilíndricos, face superior canaliculada, glabros; folíolos $2-10 \mathrm{~cm} \times 1,3-4,0 \mathrm{~cm}$, opostos, peciolulados, elípticos, obovados, base aguda, ápice agudo a arredondado, margem inteira, raramente crenada, nervura principal impressa na face superior, proeminente na face inferior, oliváceos, cartáceos. Panículas 2,5-4,0cm compr., (sub)terminais, paucifloras, pubérulas; bráctea 1,0-1,5×1 mm, oval, ápice acuminado, glabra; bractéolas $3,0,8 \times 0,9 \mathrm{~mm}$, ovais, ápice agudo; pedicelos com $0,8-1,3 \times 0,3-0,7 \mathrm{~mm}$, puberulentos. Flores masculinas, 1,5-3,6×1,9-3,5mm; sépalas 5, lacínios 0,5-0,7×0,8mm, triangulares, membranáceos, glabros; pétalas 5, 1,6-2,0×0,9-1,0mm, elípticas, membranáceas; estames 5, 1,5-2,7mm compr., exsertos, filetes 1,0-2,2mm compr., subulados, glabros, anteras $0,4-0,6 \times 0,7-0,8 \mathrm{~mm}$, ovais; pistilódio $1,0,3-7,0 \mathrm{~mm}$ compr., sobre o disco 8-9mm diâm., 5-lobado. Flores femininas não observadas. Folículos (Hoehne 5922), 4,2-5mm diâm., globosos, superfície denso-glandular; semente 1, 3,2-3,5mm diâm., arredondada, superfície lisa, hilo arredondado, preta e brilhante,.

Material examinado: BRASIL. Pernambuco: Quipapá, VII/1950, fl., Andrade-Lima 50-574 (PEUFR, IPA); São Lourenço da Mata, VIII/2000, fl., Almeida 61 (PEUFR).

Z. monogynum difere das demais espécies por apresentar folhas imparipinadas com 1-2 pares de folíolos, glabras ou ligeiramente pubescentes e flores pentâmeras.

Z. monogynum encontra-se na zona da mata de Pernambuco, em capoeirões, dentro do domínio da zona da mata meridional. No Brasil, ocorre em Alagoas, Espírito Santo, Goiás, Minas Gerais, Pernambuco, Rio de Janeiro e São Paulo (Pirani 1999). Apesar de muitas viagens de coleta, só foi possível encontrá-la no município de São Lourenço da Mata.

1.6 Zanthoxylum petiolare A. St.-Hil \& Tul., Ann. Sci. Bot., sér. 2, 17: 140. 1842.

Fig. 25-30.

Nomes vulgares: laranjinha, limãozinho e pau-barrão (PE).

Árvores ou arbustos ca. $14 \mathrm{~m}$ alt. Ramos acinzentados a castanhos escuros, geralmente com 
regiões de catáfilos ao longo dos ramos mais velhos, com ou sem acúleos, às vezes acúleos com base espessa, retos ou levemente recurvados para baixo, glabros. Folhas paripinadas ou imparipinadas, raques $5-23 \mathrm{~cm}$ compr., com 3-5 pares de folíolos, subaladas, glabras; pecíolos 2,5-7,5cm compr., semicilíndricos, canaliculados na face superior, glabros; folíolos 3,5-13,0×1,5-6,0cm, (sub)opostos, (sub)sésseis, ovais a elípticos, base oblíqua, geralmente falcada, ápice cuspidado, margem crenulada, membranáceos a cartáceos, nervura principal impressa na face superior e proeminente na face inferior, glabros. Panículas 4,5-10,5cm compr., terminais e axilares, multifloras, pedúnculos principal e lateral angulosos, pubescentes; bráctea 1, 0,6-1,3mm compr., lanceolada; bractéola 1, 0,9-2,1 mm compr., lanceolada; botões florais 2,0-2,2mm compr., globosos; pedicelos ca. $0,2 \mathrm{~mm}$ compr. Flores masculinas ca. $2 \mathrm{~mm}$; sépalas 5, 0,7-1,1mm compr., lacínios oval-triangulares, glabros; pétalas 5, ca. 2,1×1-1,5mm, elípticas, côncavas; estames 5, ca. $4 \mathrm{~mm}$ compr., exsertos, filetes $3 \mathrm{~mm}$ compr., subulados, glabros; pistilódio ca. $0,7 \mathrm{~mm}$ compr., piriforme. Flores femininas ca. 1,5-3,9mm compr.; pedicelos ca. $0,5 \mathrm{~mm}$ compr.; sépalas 5, 0,8-1,0×0,9-1,1mm, ovais, ápice obtuso, membranáceas, glabras; pétalas 5, 1,8-2,1× 1,0-1,7mm, ovais a oblongas, côncavas, com nervura central conspícua, membranáceas, glabras; carpelos 2-3, conados na base, sobre o ginóforo, glabros, tuberculados. Folículos 3,5-6,0mm diâm., globosos, superfície glandular; semente 4-5mm, ovóide, preta, brilhante, hilo arredondado a linear.

Material selecionado: BRASIL. Pernambuco: Agrestina, IX/98, veg., Melo 125 (PEUFR); Bodocó, II/1984, fl., Fotius \& Sá 3719 (IPA); Floresta, V/1971, fr., Heringer 792 (IPA); Limoeiro, II/1960, fr., Andrade-Lima 66-4504 (IPA); Nazaré da Mata, XII/1953, fl., Moraes s.n. (EAN 1009); Recife, I/1978, fl., fr., Coelho s.n. (IPA); Santa Cruz da Baixa Verde, II/199, fl., Melo 187 (PEUFR); São Vicente Férrer, IV/1999, fr., Melo 245 (PEUFR); Triunfo,VI/1992, fr., Ferraz 161(IPA).

Z. petiolare caracteriza-se por apresentar folíolos glabros, membranáceos, flores congestas, pentâmeras, branco-esverdeadas, com 2 ou mais carpelos. Esta espécie é próxima de $Z$. gardneri por possuir folíolos glabros e elípticos, diferenciando-se principalmente pelo ápice destes. A ausência de tricomas na lâmina foliar a separa de duas outras espécies, Z. stelligerum e $Z$. rhoifolium, já que estas possuem tricomas estrelados.

As flores femininas de $Z$. petiolare apresentam o ginóforo mais desenvolvido do que $Z$. rhoifolium. Pirani (1999) e Albuquerque (1976) trataram o ginóforo das flores femininas de Zanthoxylum como disco ginoforóide (colunar). Contudo, Beurton (1994), com o objetivo de esclarecer a morfologia, reconheceu o ginóforo como uma estrutura do perianto formada pela estipe localizada na base do ovário, geralmente curtas em todas as espécies de Zanthoxylum, com exceção de Z. americanum Mill., Z. friesii (Fries) Watterman e Z. fagara (L.) Sarg. que apresentam estipe longa.

Escalante (1961) e Spichiger \& Ortega (1987) citaram sua ocorrência na Argentina, Bolívia, Paraguai. No Brasil, ocorre em quase todas as regiões, com exceção da região Norte. Em Pernambuco, está amplamente distribuída, partindo da região metropolitana do Recife até a parte oeste do Estado, conhecida nos municípios de Recife, Agrestina (Zona do litoral), Limoeiro, Nazaré da Mata (Zona da Mata), São Vicente Férrer (Zona do Agreste), Floresta, Santa Cruz da Baixa Verde, Triunfo e Bodocó (Zona do Sertão), porém os indivíduos são pouco freqüentes. Ocorre em solos arenosos com presença de afloramento rochoso, com ou sem serrapilheira. São comuns em capoeirões, floresta residual de baixada até florestas a $960 \mathrm{~m}$ de altitude, ocorrendo preferencialmente nas bordas de matas ou com vegetação menos densa.

1.7 Zanthoxylum rhoifolium Lam., Encycl. 2(2): 39. 1768.

Fig. 31-35.

Nomes vulgares: laranjinha-do-mato, limãozinho, cafezinho (PE), mamica-de-porca, tinguaciba-da-folha miúda, espinho-de-vintém, mamica-de-cadela, teta-decadela, tambatarão (Sudeste e Sul do Brasil), tamanqueira-de-espinho, tamanqueira-limão, carne-de-anta, tembetaru (Amazônia), juva, juvevê (Sul do Brasil).

Árvores, arvoretas ou arbustos 5-23m alt. Ramos geralmente aculeados, puberulentos ou com indumento simples, raramente estrelado, acinzentados a castanho-esverdeados. Folhas imparipinadas a paripinadas, raques $8-37 \mathrm{~cm}$ compr., subaladas, $4-13$ pares de folíolos, com ou sem acúleos na face inferior, indumento esparso-estrelado na face inferior, raramente simples; pecíolos 1,2-6,0cm compr., semicilíndrico, canaliculado na face superior, esverdeados a vináceos, recobertos por indumento ferrugíneo a esbranquiçado, simples e estrelado; folíolos basais $0,9-4,0 \times 0,6-2,4 \mathrm{~cm}$, apicais $3,2-8,0 \times 1,3-3,2 \mathrm{~cm}$, (sub)opostos, peciolulados, às vezes subsésseis, oblongos, elípticos, ovais, base oblíqua, ápice agudo, acuminado, margem crenada, membranáceos a cartáceos, com tricomas estrelados esparsos em ambas as faces, mais densos na base. Panículas 4,9-16,0cm compr., terminais e axilares, multifloras, com indumento 


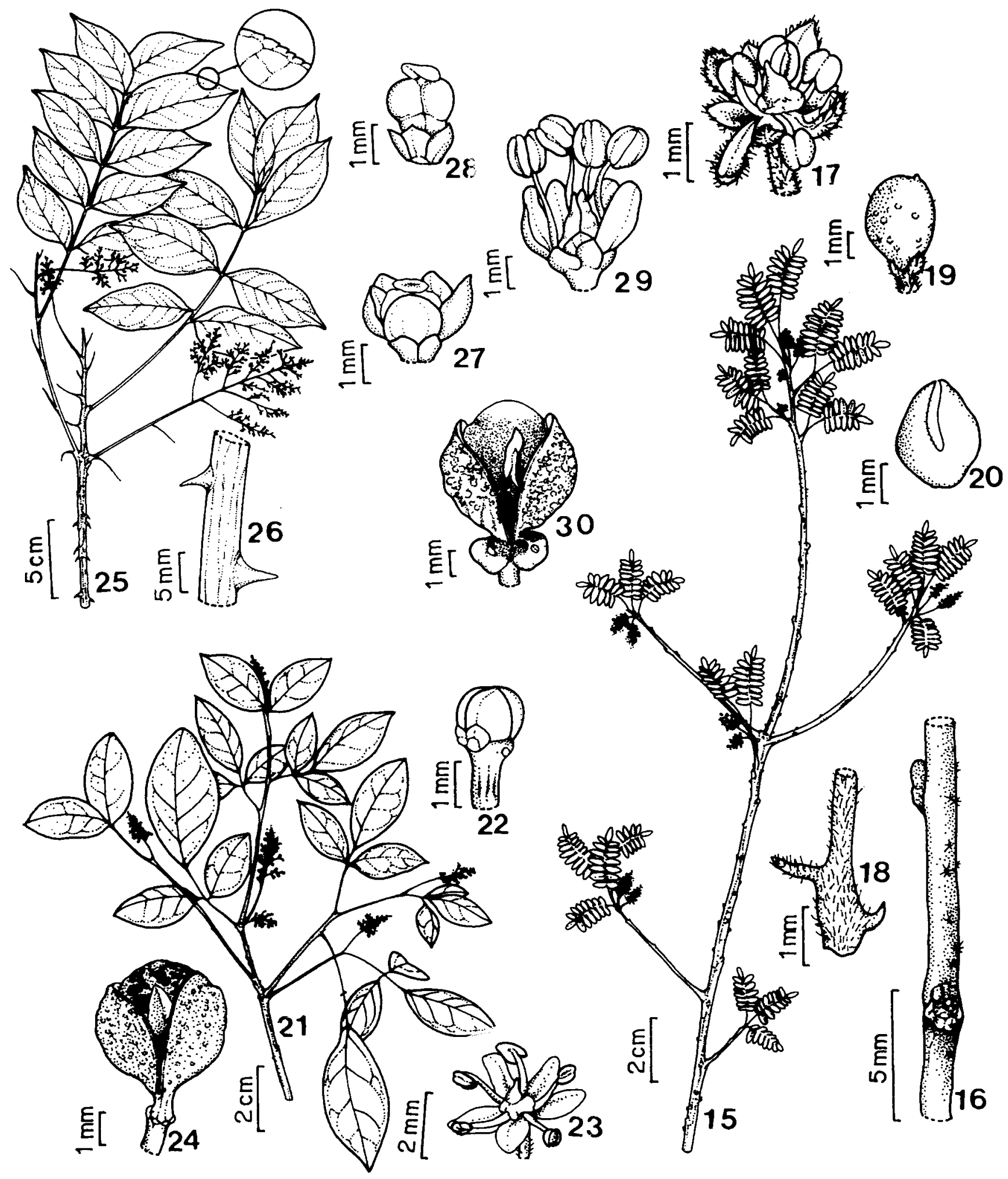

Figuras 15-20. Zanthoxylum hamadryadicum. 15. Hábito. 16. Detalhe do ramo. 17. Flor masculina, evidenciando estames e pistilódio. 18. Detalhe das brácteas (Lemos 54). 19. Folículo. 20. Semente (Chiapetta s.n., PEUFR 7327). Figuras 21-24. Zanthoxylum monogynum. 21. Hábito (Hoehne 5922). 22. Detalhe do botão (Andrade Lima 5922). 23. Flor masculina evidenciando estames e pistilodio (Almeida 161). 24. Folículo aberto evidenciando semente (Hoehne 5922). Figuras 25-30. Zanthoxylum petiolare. 25. Hábito. 26. Detalhe dos acúleos. 27. Flor feminina. 28. Gineceu evidenciando ginóforo (Melo 187). 29. Flor masculina evidenciando estames e pistilódio (Hatsbach 4826). 30. Folículo evidenciando semente (Melo 245). 
estrelado nos eixos principal e lateral, raramente simples; bráctea 1, 0,6-0,8mm compr., ciliada, face externa pilosa; bractéolas 3, 0,2-0,5mm compr., face externa com indumento tomentoso; botões florais 1,4-1,6mm compr., globosos, pedicelos $0,8-1,8 \mathrm{~mm}$ compr., denso-estrelados. Flores masculinas 1,8-2,5mm compr.; cálice concrescido na base; sepálas 5, lacínios 0,3-0,6×0,5-1,0mm, triangulares, externamente com indumento estrelado, margem ciliada; pétalas 5, 0,7-0,9×1,0mm, côncavas, elípticas a oval-elípticas, nervura central conspícua, glabras; estames 5, 1,1-2,6mm compr., exsertos, inseridos sob disco anular, filetes 0,9-2,1mm compr., subulados, anteras 0,5-0,8mm compr, ovais; pistilódio 1, ca.1,2mm compr., glabro. Flores femininas com 1-2 carpelos, unidos na base ou pelo estigma, sobre ginóforo, 1-2 óvulos, estigma discóide, subséssil ou peltado. Folículos 3-5×2-4mm, globosos, superfície glandular saliente; semente 3-4×2-3mm, esférica, funículo longo, hilo linear, lisa, preta e brilhante.

Material selecionado: BRASIL. Pernambuco: Abreu e Lima, V/1999, veg., Melo 232 (PEUFR); Bonito, III/1999, fl., Melo 207 (PEUFR); Bezerros, VI/1998 fr., Santos 219 (PEUFR); Brejo da Madre de Deus, XII/1998, veg. Melo 156 (PEUFR); Caruaru, II/1999, veg., Melo 166 (PEUFR); Condado, X/1998, veg., Melo 145 (PEUFR); Floresta, I/1997, fl., fr., Nascimento 61 (PEUFR); Itambé, XII/ 1998, veg., Melo 150 (PEUFR); Paulista, IV/1984, fl., Chiappeta 455 (UFP); Pesqueira, IX/1995, fr., Ferreira \& Eduardo s.n. (55774 IPA); Recife, 11/1998, veg., Melo 259 (PEUFR); São José do Belmonte, X/1971, fl., Ramalho 53 (HST); São Lourenço da Mata, V/1999, fl., bot., Melo 238 (PEUFR); Santa Cruz da Baixa Verde, II/1999, fl. Melo 187 (PEUFR); São Vicente Férrer, IV/1999, fr., Melo 222 (PEUFR); Tacaratu, III/1983, fr, Chiappeta et al. 42 (IPA); Triunfo, II/1999, fl., Melo 185 (PEUFR); Vitória de Santo Antão, IX/1999, fr., Melo et al. 246 (PEUFR).

Zanthoxylum rhoifolium é uma das espécies de maior polimorfismo, principalmente quanto ao número e tamanho do folíolos, textura e densidade dos tricomas. Provavelmente, isso ocasionou diferentes descrições e nomes. Até o momento, possui em sua sinonímia 24 binômios (Pirani 1999). No campo, é facilmente reconhecida pelo porte arbóreo geralmente com folhas, tronco, ramos aculeados. Apresenta mais de dez pares de folíolos; frutos globosos com glândulas salientes.

Quando comparada a outras espécies, aproxima-se de Z . stelligerum. $\mathrm{O}$ que a diferencia é a presença de tricomas estrelados esparsos na face inferior da lâmina foliar e frutos globosos com semente esférica.
Espécie com ampla distribuição, sendo encontrada na Argentina, Bolívia, Brasil, Colômbia, Equador, Paraguai e Venezuela (Cowan 1960; Escalante 1961). Em Pernambuco, apresenta ampla distribuição, ocorrendo nas diferentes mesoregiões, desde a Região Metropolitana do Recife até o sertão de Pernambuco, nos municípios de Abreu e Lima, Recife (Zona do Litoral), Condado, São Lourenço da Mata, Vitória de Santo Antão (Zona da Mata), Bezerros, Bonito, Brejo da Madre de Deus, Caruaru, Pesqueira, São Vicente Férrer (Zona do Agreste), Floresta, Triunfo, Tacaratu (Zona do Sertão). A espécie ocorre no interior e bordas de matas, terrenos incultos, campos abertos, mata nebular e floresta serrana, preferencialmente, em solos arenosos a areno-argilosos. Grande parte do material coletado em Pernambuco registrou em seu habitat natural a presença de afloramentos rochosos.

1.8 Zanthoxylum stelligerum Turcz., Bull. Soc. Imp. Naturalistes Moscou 31: 442. 1858.

Fig. 36-39.

Nomes vulgares: umbuzeiro-brabo, laranjinha (PI, $\mathrm{PE})$, laranjeira-braba (BA), limãozinho (CE), jurubebade-chapada (PI).

Árvores ou arbustos 3,5-6,0m alt. Ramos cilíndricos com indumento estrelado, ferrugíneo quando jovens, glabrescentes quando velhos, com ou sem acúleos, 1,5-4,0cm compr., retos ou pontiagudos, mais ou menos pilosos. Folhas imparipinadas, raques $4,0-8,5 \mathrm{~cm}$ compr., 3-5 pares de folíolos, subaladas, densamente recobertas por indumento estrelado, ferrugíneo; pecíolos cilíndricos, denso-estrelados; folíolos basais $0,9-3,5 \times 1,0-1,9 \mathrm{~cm}$, apicais $2,0-5,9 \times 0,9-2,5 \mathrm{~cm}$ compr., face superior esparso-estrelada, face inferior denso-estrelada, (sub)opostos, (sub)sésseis, ovais, elípticos, base obtusa, arredondada, ápice agudo, acuminado, margem crenulada, membranáceos. Panículas 5,0-11,5cm compr., terminais, multifloras; bráctea 1, 1,0-1,2mm compr.; bractéolas 2-3, 0,5-0,7mm compr., face externa com tricomas estrelados; pedicelos $0,2-1,0 \mathrm{~mm}$ compr. Flores masculinas $2-4 \times 1,5-3,5 \mathrm{~mm}$; sépalas 5 , lacínios 0,5-1,2×1,0-1,5mm, triangulares, margem ciliada, glandulas próximas ao ápice, recobertos por indumento estrelado; pétalas 5, 2-2,5×1,0mm, oval-elípticas, côncavas, nervura central conspícua, glabras; estames 5, 1,1-3,4mm compr., exsertos, inseridos sob disco lobado, ca. 0,5mm de diâm., filetes $0,6-2,9 \mathrm{~mm}$ compr., subulados, glabros, anteras, $0,5-0,9 \times 0,5-0,7 \mathrm{~mm}$, ovais, glabras; pistilódio 1-3, ca. 0,5mm compr., unidos na base. Flores femininas $3,0-3,3 \times 2,0 \mathrm{~mm}$; pedicelo ca. $1 \mathrm{~mm}$ compr., indumento estrelado; carpelos 2, livres, 
estaminódios 5, glabros, ginóforo ca. $0,4 \times 0,9 \mathrm{~mm}$, estigma discóide, peltado, (Andrade-Lima 52-133 \& Magalhães). Folículos ca. 3mm diâm., sub-globosos, bivalves, superfície glandular; semente ca. $2,3 \mathrm{~mm}$, elipsóide, hilo linear, preta.

Material examinado: BRASIL. Pernambuco: Betânia,VIII/1978, fr., Gonçalves 20 (IPA); Buíque, II/1999, veg., Melo 183 (PEUFR); Inajá, I/1958, fl., Andrade Lima 58-2860 (IPA); São José do Belmonte, IX/1998, fl., Carvalho 60 (PEUFR); Tacaratu, VII/1990, fr., Bocage 200 (IPA); Tupanatinga, X/1983, fl., fr., Gallindo \& Lima 45 (IPA).

Z. stelligerum é uma espécie de fácil reconhecimento no campo. São arbustos ou arvoretas com acúleos longos e pontiagudos, flores esverdeadas, folíolos (sub)sésseis, ovais a elípticos, densamente recobertos por tricomas estrelados. Esta espécie tem ambiente preferencial no sertão de Pernambuco, ocorrendo em área de caatinga, cerrado, carrasco e capoeira. Segundo Pirani (1999), esta espécie distribui-se no norte de Minas Gerais e Nordeste do Brasil, nos Estados da Bahia, Ceará, Pernambuco e Piauí.

1.9 Zanthoxylum syncarpum Tul., Ann. Sci. Nat. Bot., sér. 7: 279. 1847.

Fig. 40-45.

Nomes vulgares: espinho-de-barrão (PE) e limãozinho (PE).

Árvores, arvoretas ou arbustos ca. 9m alt. Ramos aculeados, glabros, às vezes pubescentes na região apical, castanhos. Folhas imparipinadas, raques $5-13 \mathrm{~cm}$ compr., levemente aladas, com 1-3 pares de folíolos; pecíolos 1,5-3,0cm compr., semicilíndricos, planos e canaliculados na face superior, denso a esparsamente recobertos por indumento hirsuto, hialino; folíolos basais 1,0-3,5×0,9-3,2cm, apicais 2,2-10,0×0,9-4,0cm compr., (sub)opostos, sésseis, elípticos, às vezes obovados, base atenuada, ápice obtuso, acuminado, margem crenada com tricomas hirsutos densos a esparsos nas nervuras principal e lateral em ambas as faces, membranáceos a cartáceos. Racemos 1,0-3,5cm compr., terminais, intercalados por folhas, paucifloras, recobertas por indumento hirsuto; bractéola 1, 1,8-3,2×0,8-0,9mm, oval a lanceolada; pedicelos $3,8-5,2 \times 0,6-0,8 \mathrm{~mm}$, recobertos por indumento hirsuto. Flores masculinas $2,8-3,2 \mathrm{~mm}$; pétalas 5, 2,8-3,0×1,2-1,4mm, côncavas, oval-elípticas, face externa recoberta por tricomas simples, nervura média conspícua; estames 5 , ca. $2 \mathrm{~mm}$ compr., inseridos sob o disco 5-lobado, ca. 1,5mm diâm., filetes $0,6-1,0 \mathrm{~mm}$ compr., subulados, glabros, anteras ca. $1,1 \times 1,2-1,5 \mathrm{~mm}$, ovais; pistilódio único, bi ou tripartido, ca. $0,5-0,8 \mathrm{~mm}$ compr., com poucos tricomas simples próximos do ápice. Flores femininas ca. $4 \mathrm{~mm}$ compr.; pedicelos longos ca. $7 \mathrm{~mm}$ compr., recobertos por indumento hirsuto; sépalas 5 , lacínios 0,8-1,2mm compr., triangulares, livres, face externa recoberta por indumento hirsuto; pétalas 5, ca. $4,5 \mathrm{~mm}$, oblongas, face interna glabra, face externa recoberta por indumento hirsuto da base em direção ao ápice; carpelos 3-5, conados axial e lateralmente, densohirsuto, estigma discóide, sub-séssil. Cápsula 6,5-6,7×7,0-7,5mm, sub-globosas e muricadas, com tricomas simples, deiscência loculicida e septicida, carpelos unidos axial e lateral 3/4 do seu comprimento; semente ca. $2,8 \times 1,5 \mathrm{~mm}$, elipsóide, hilo linear, preta, fosca ou brilhante.

Material examinado: BRASIL. Pernambuco: Buenos Aires, V/199, veg., Melo 236 (PEUFR); Itambé, XII/1998, Melo 151 (PEUFR); Itambé X/1999, fr., Melo 253 (PEUFR); Nazaré da Mata, I/1955, fl., Moraes s.n. (EAN 1424, 1425).

Espécie bem delimitada e facilmente reconhecida no campo. Caracteriza-se principalmente por apresentar espinhos eretos, longos e pontiagudos, folhas com 2-3 pares de folíolos elípticos, raque estreitamente alada. Os frutos são muricados, com carpelos unidos axial e lateralmente por 3/4 ou mais do seu comprimento.

A espécie encontra-se distribuída principalmente na zona da mata de Pernambuco (Buenos Aires, Itambé e Nazaré da Mata), particularmente nas matas mais úmidas, podendo chegar nas matas secas. Ocorre em terrenos arenosos, nas bordas de matas e áreas de clareiras. É freqüente no município de Itambé, apresentando variações morfológicas dentro da população, principalmente em relação ao tamanho dos folíolos e densidades dos tricomas. A distribuição da espécie é restrita ao Nordeste do Brasil, citada para o Ceará, Rio Grande do Norte, Paraíba e Pernambuco (Pirani 1999).

\section{Esenbeckia Kunth}

Árvores, arbustos ou arvoretas de tamanho médio. Ramos cilíndricos, lenticelados, casca lisa ou com placas irregulares, indumento seríceo e tomentoso, geralmente translúcidos, raramente esbranquiçados. Folhas com grande variação intra-específica, alternas ou subopostas, simples ou compostas, 1-5 folioladas, margem inteira, geralmente revoluta, glabras, pubérulas ou pilosas, principalmente na base ou nervura principal, membranáceas a cartáceas, nervação do tipo broquidódromo. As inflorescências são tirsos ou panículas, às vezes de tamanho reduzido ( $\pm 1,0 \mathrm{~cm}$ em E. almawillia, Fig. 46), terminais, axilares ou laterais, pauci ou multifloras. Flores 


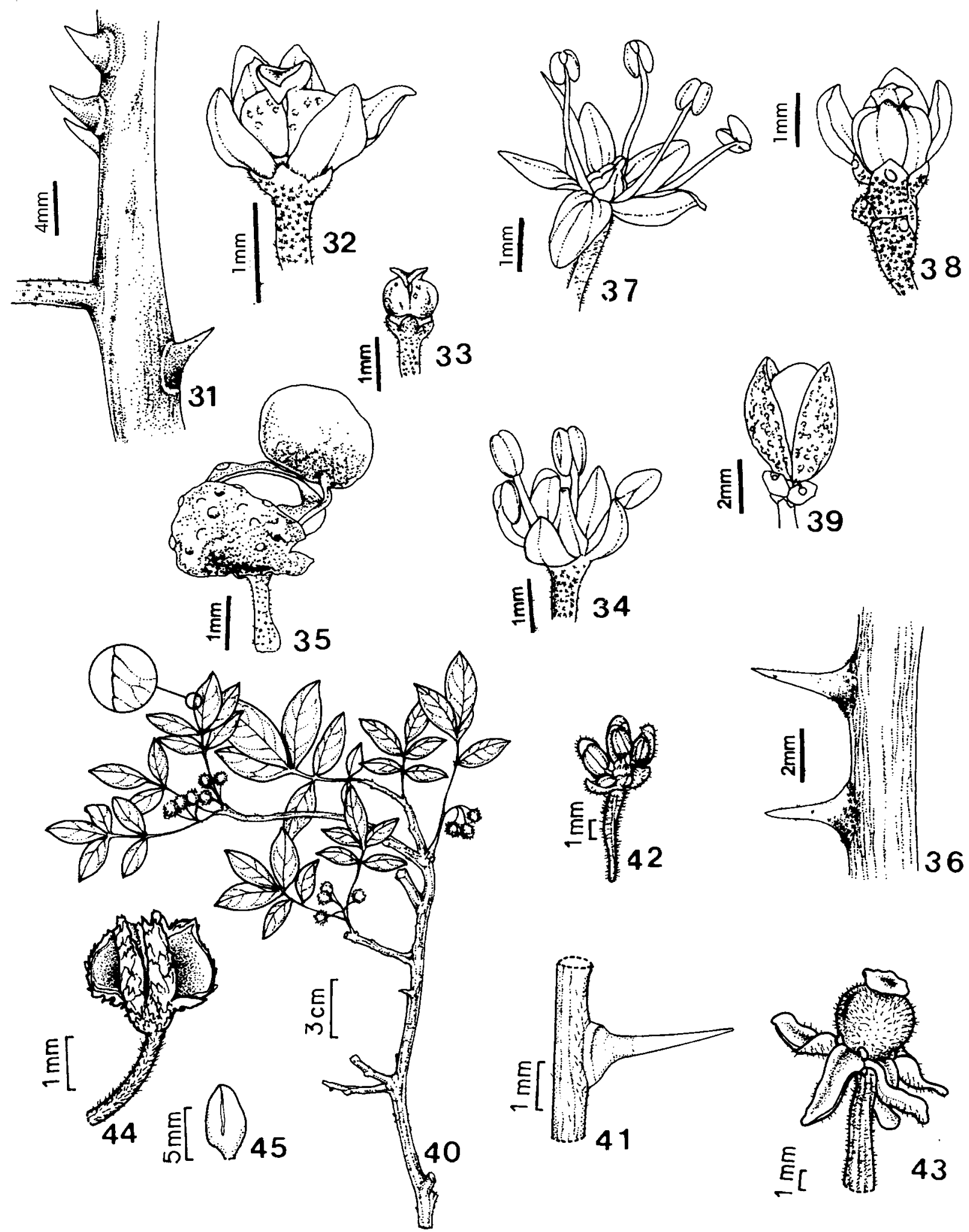

Figuras 31-35. Zanthoxylum rhoifolium. 31. Detalhe dos Acúleos (Tschá 1872). 32. Flor feminina. 33. Detalhe do gineceu (Chiappeta 445). 34. Flor masculina (Melo 185). 35. Folículo aberto evidenciando semente (Melo 232). Figuras 36-39. Zanthoxylum stelligerum. 36. Detalhe dos acúleos (Melo 201). 37. Flor masculina evidenciando estames e pistilódio (Harley 18915). 38 Flor feminina evidenciando gineceu (Galliodo 45 et al.). 39. Folículo aberto evidenciando semente (Lima 13277). Figuras 40-45. Zanthoxylum syncarpum. 40. Hábito (Moraes s.n., EAN 1424). 41. Detalhe do acúleo (Felix 5705). 42. Flor masculina (Moraes s.n., EAN 1425). 43. Flor feminina (Félix 5705, EAN). 44. Cápsula aberta. 45. Semente (Melo 253, PEUFR). 
bissexuais, 4-5 sépalas e pétalas; cálice lobado, prefloração quincuncial (Fig. 49); pétalas livres, patentes ou reflexas (Fig. 63) ou oblonga oval, sub-circular, elíptica ou oblonga, prefloração valvar a imbricada, membranáceas a carnosas, esverdeadas até amarelas; estames 5, livres, alternipétalos, inseridos na base, geralmente nos sulcos presentes entre os lobos do disco (Fig. 58), filete subulado, base levemente achatada ou dilatada, antera dorsifixa, versátil em todas as espécies, geralmente cordiforme, raramente cuculada angulosa (Fig. 59); ovário sub-globoso, imerso no disco intraestaminal, 5-lobado (Fig. 58) ou cupular (Fig. 47), freqüentemente recoberto por protuberâncias verrucosas, arredondadas ou alongadas; carpelos 5 , conados ou parcialmente conados na base, 1-2 óvulos por lóculo, estilete cilíndrico, estigma capitado. Cápsula lenhosa (Fig. 53), muricada até equinada, 5 mericarpos, deiscência simultânea septicida e loculicida, cada carpelo com endocarpo elástico, desprendendo-se do resto do pericarpo bivalvar; sementes 1-2 por lóculo, hilo distinto e área chalazal geralmente evidente próxima da base na face ventral. De acordo com Pirani (1999), o endosperma às vezes é presente; embrião 1 a vários; cotilédone espesso, base auriculada.

O gênero Esenbeckia Kunth com aproximadamente 30 espécies, está distribuído nas Américas, do sul dos Estados Unidos (Texas), nordeste do México até o Chile, Argentina e Brasil (Record \& Hesss 1940). Os principais centros de diversidade estão no sudeste do Brasil e no México, sendo raro no leste da Índia (Kaastra 1982).

Chave para identificação das espécies de Esenbeckia ocorrentes em Pernambuco

1. Inflorescências em panículas laterais até $1,2 \mathrm{~cm}$ compr. 1. E. almawillia

1. Inflorescências em panículas terminais ou axilares, maiores que $2 \mathrm{~cm}$ compr.

2. Folhas simples; flores externamente recobertas com tricomas seríceos

4. E. leiocarpa

2. Folhas compostas 1-5 folioladas; flores externamente sem tricomas seríceos

3. Pecíolos estreito-alados; flores com ovário piloso; fruto com apófise 5. E. pilocarpoides

3. Pecíolos não alados; flores com ovário glabro a pubérulo; fruto sem apófise

4. Folhas unifolioladas; flores com pétalas patentes ..... 3. E. grandiflora

4. Folhas trifolioladas; flores com pétalas ascendentes 2. E. febrifuga

2.1 Esenbeckia almawillia Kaastra, Acta Bot. Neerl. 26: 481, t.6. 1977.

Fig. 46-47.

Arbustos 1-2m alt. Ramos castanho-acinzentados, glabrescentes. Folhas 2-4,8×1,0-2,1 cm, alternas, unifolioladas; peciolos 3-4mm compr., semicilíndricos, levemente planos e canaliculados na face superior, pubescentes; folíolos 2,0-4,8×1,0-2,1 cm, estreito-elípticos, sésseis, base aguda ou obtusa, ápice obtuso, levemente acuminado, emarginado, margem revoluta, puberulentos, às vezes mais densos na margem e nervura principal em ambas as faces, nervura principal impressa na face superior, proeminente na face inferior, diminuindo de calibre próxima do ápice, coriáceos. Panículas, 0,4-1,2cm compr., laterais, intercaladas por folha, paucifloras; bráctea não observada, bractéolas 2 , ca. $0,7 \times 0,4 \mathrm{~mm}$, estreito-triangulares, recobertas por tricomas tomentosos. Flores ca. 1,7-1,8mm diâm.; sépalas 5, 0,7-1,1mm compr., triangulares, concrescidas na base, recobertas por indumento seríceo; pétalas 5, ca. $2,1 \times 1,0 \mathrm{~mm}$, ovais a elípticas, ápice agudo, externamente recobertas por tricomas seríceos, internamente glabras ou tricomas simples, translúcidos; estames 5, ca. 1,3mm compr., filetes $0,9-1,2 \mathrm{~mm}$ compr., subulados, glabros, anteras ca. $0,5 \times 0,5 \mathrm{~mm}$, cordiformes, puberulentas; disco ca. 1,2mm diâm., cupuliforme, 5-lobado, conado na base do ovário, glabro; carpelos 5, conados, com 1 apófise em cada carpelo, densamente recobertos por tricomas tomentosos, uniloculares, com 2 óvulos por lóculo, estilete ca. $0,5 \mathrm{~mm}$ compr. acima do ovário, inserido entre as pontas dos carpleos, cilíndrico, glabro ou puberulento; estigma 0,2-0,4mm compr., capitado. Fruto não observado.

Material examinado: BRASIL. Pernambuco: Araripina, VI/1952, fl., Andrade-Lima \& Magalhães 52-1070 (IPA, PEUFR).

A espécie é reconhecida pelas inflorescências em panículas muito curtas e laterais, com flores recobertas por indumento seríceo.

De acordo com Kaastra (1982), E. almawillia ocorre na Bolívia, nas áreas de Santa Cruz e Pando. No Brasil está distribuída nos Estados do Acre e Pernambuco. Contudo, Pirani (1999) registra pela primeira vez a ocorrência dessa espécie na Bahia, Maranhão e Minas Gerais. 
2.2 Esenbeckia febrifuga (A.St.-Hil.) Juss. ex Mart., Nov. Gen. Sp. Pl. 3: 82, t. 233. 1831.

Euodia febrifuga A. St.-Hil., Bull. Sci. Sco. Philom. 129. 1823.

Fig. 48-56.

Nomes vulgares: três-folhas-vermelhas, laranjeirado-mato.

Árvores ou arbustos até $11 \mathrm{~m}$ alt. Ramos amarelo-acinzentados a castanho-avermelhados, glabrescentes. Folhas (sub)opostas, 3-folioladas; pecíolos 1,6-5,4cm compr., semicilíndricos, canaliculados, subalados, pubérulos; folíolos centrais 5,5-12,0× 1,7-4,2cm, laterais, 2,6-8,5×1,5-4,0cm, elípticos, base oblíqua, atenuada a cuneada, ápice acuminado, raramente emarginado, margem revoluta, face superior glabra, raramente pubérula, face inferior pubescente na base e na nervura principal, indumento simples, raramente espalhando-se na nervuras laterais até $2 / 3$ do comprimento, membranáceos a cartáceos. Panículas 6-12 cm compr., terminais, eretas, geralmente menores do que as folhas, multifloras, pubescente; bráctea 1 , 1-2mm compr., oval com ápice acuminado, pubérula; bractéolas 2-3, 1,0-1,2mm compr., ovais com ápice acuminado, glabras a pubérulas; pedicelos 1,2-1,6mm compr., pubescentes. Flores ca. $5 \mathrm{~mm}$ diâm., protandras; sépalas 5, 1,2mm compr., ovais com ápice obtuso, glabras, às vezes pubescentes na base, membranáceas, amarelas claras; pétalas 5, 1,8-2,3×1,0-1,2mm, elípticas ou oblongo-elípticas, margem revoluta, glabras a levemente pubescentes; estames 1,0-1,5mm compr., filetes subulados, côncavos, glabros, anteras 0,3-0,5×0,3mm, cordiformes; disco 1,0-1,6mm diâm., 0,5-0,7mm alt., 5-10 lobado, cupuliforme, glabro; carpelos 5, base depressa, 2 óvulos por lóculo, conados, recobertos com protuberâncias fusiformes com pontas arredondadas ou pontiagudas, 0,1-0,2mm compr., glabros, às vezes, com poucos tricomas, estilete $0,8-1,0 \mathrm{~mm}$ compr., inserido na base dos carpelos, glabro, estigma capitado. Cápsulas 10,5-13,0mm diâm., sub-globosas, muricadas, glabras, destituídas de apófise, deiscências septicida e loculicida; sementes 4,6×3,0-3,5mm, ovais, 2 por lóculo, base truncada, ápice acuminado, hilo linear, testa granulosa, marrom escura.

Material examinado: BRASIL. Pernambuco: Bezerros, VII/1977, fl., Andrade Lima 77-8307 (IPA); Jataúba, IV/1966, fl., Andrade Lima 66-4512 (IPA); Panelas, VII/1966, fl., Andrade Lima 66-470 (IPA).

Espécie bem caracterizada por apresentar folhas trifolioladas, membranáceas, com indumento simples na face inferior do folíolo, na base da nervura principal em direção ao ápice. A panícula é multiflora, geralmente mais longa que as folhas.

Pode ser encontrada na Argentina e Paraguai. No Brasil, ocorre nos Estados do Ceará, Mato Grosso, Minas Gerais, Paraná, Rio de Janeiro e São Paulo. Em Pernambuco, foi encontrada em Bezerros, Jataúba e Panelas. Até o momento, encontra-se na Zona do Agreste, com ocorrência em capoeiras.

De acordo com Lorenzi (1982), ocorre em floresta semidecídua da bacia do Paraná e na parte elevada da floresta Atlântica, mas com pouca ocorrência em floresta de restinga.

2.3 Esenbeckia grandiflora Mart., Nov. gen. sp. pl. 3: 85.1831.

Fig. 57-61.

Nomes vulgares: limãozinho (PE), gramicho (RN), guarantam (SP), cocão (CE), cipó, garajaú (PB).

Arbustos, arvoretas ou árvores 4-7m alt. Ramos castanhos a castanho-acinzentados, fendas longitudinais pouco esfoliantes, glabrescentes com tricomas ferrugíneos. Folhas alternas, unifolioladas; pecíolos 0,6-2,5cm compr., estriados, semicilíndricos, face superior canaliculada, pubescente, raramente glabra; folíolos 3,0-14,5cm compr., obovados, elípticos, sésseis, glabros a pubérulos, base cuneada, aguda, ápice obtuso, agudo, margem inteira, revoluta, coriáceos. Panículas 3,0-14,5cm compr., terminais ou axilares, eretas, paucifloras, pubescentes; bráctea 1 e bractéolas 2-3, oval-acuminadas, geralmente opostas, côncavas, cartáceas, recobertas por tricomas estrigosos, mais densas na base, com margem ciliada; pedicelos 3-6mm compr., densamente recobertos por indumento estrigoso. Flores 6-9mm diâm.; sépalas 5, largamente ovais, ápice arredondado, obtuso , margem ciliada; pétalas 5, 2,5-6,0×3,0-6,2mm, ovais a elípticas, patentes; estames 5, 1,7-5,2mm compr., filetes 1,5-5,0mm compr., subulados, glabros ou com tricomas translúcidos na base, anteras 0,5-2,0mm compr., base cordiforme ou cuculada-angulosa, raramente com ápice mucronado, dorsifixas; disco 2,0-3,5mm diâm., 0,5-1,5mm alt., 5-lobado, anular, sulcado, pubérulo, raramente glabro; carpelos 5, coalescentes, uniloculares, recobertos por protuberâncias $0,5-3,0 \mathrm{~mm}$ compr., oblongas, ou pontiagudas, glabras ou pubescentes, às vezes com 1 ou 2 protuberâncias maiores; estilete 1,0-1,2× 0,5-0,6mm, acima da superfície do ovário, piloso, estigma $0,5-0,7 \times 0,7-1,0 \mathrm{~mm}$, capitado. Cápsulas 8,5-24,0×17,5-24,6mm, globosas, deiscência loculicida e septicida, equinadas, com espinhos de base alargada, com ápice agudo, glabros ou pilosos; sementes ovais, 
base truncada, depressa, ápice agudo, hilo linear, castanhas.

Material selecionado: BRASIL. Pernambuco: Araripina, I/1952, fl., Andrade-Lima \& Magalhães 52-1070 (PEUFR); Camaragibe, VIII/1950, fl., Andrade Lima 50637 (IPA); Itambé, VIII/1952, fr., Magalhães s.n. (IPA 12602); Goiana, sem data, fl., Guedes 1719 (PEUFR); Quipapá, III/1967, fr., Andrade-Lima 67-4972 (IPA); Recife, I/1981, fr., Ehrendorrfer s.n. (IPA 44564); Recife, IV/1963, fr., Andrade Lima 634173 (IPA); Recife, V/1950, fl., Andrade Lima 50-482 (IPA); Rio Formoso, IX/84, fr., Galindo s.n. (IPA 49728); Serinhaém, XII/1991, fr., Lima s.n. (IPA52656); Timbaúba, XII/1999, fr., Melo 159 (PEUFR).

Espécie facilmente reconhecida no campo pelo porte arbustivo ou arvoreta, com copa estreita, geralmente com folhas dispostas nas terminações dos ramos, folíolos largo-elípticos, flores pentâmeras, branco-esverdeadas e frutos muricados.

E. grandiflora está entre as espécies de maior distribuição no Estado, no domínio das zonas da mata e litoral (Itambé, Goiana, Quipapá, Recife, Rio Formoso, Serinhaém e Timbaúba). Espécie com ampla distribuição no Brasil, em áreas de tabuleiros arenosos, restingas, matas costeiras e lugares úmidos, principalmente nas margens de riachos com afloramentos rochosos. $\mathrm{Na}$ região Sudeste ocorre principalmente na floresta latifoliada semidecídua (Lorenzi 1992).

2.4 Esenbeckia leiocarpa Engl. in Mart., Fl. bras. 12(2):145, t.32, fig. 1.1874.

Fig. 62-64.

Nomes vulgares: guarantã (SP), guarataia-vermelha (ES)

Arbustos ou árvores 5-12m alt. Ramos castanhos, recobertos por indumento tomento translúcido, geralmente com cicatrizes foliáceas. Folhas 5-10×3,3-6,5cm, simples, alternas a subopostas; pecíolos $1,8-2,5 \mathrm{~mm}$ compr., semicilíndricos, levemente canaliculados na face superior, pubescentes; lâmina foliar obovada a largoelíptica, base aguda a atenuada, ápice obtuso, arredondado, raramente emarginado, margem revoluta, glabra a puberulenta, às vezes com nervuras principal $\mathrm{e}$ lateral pilosas, cartácea. Panículas 6,5-12,0cm compr., amplas, terminais e axilares, mais longas do que as folhas, multifloras, indumento seríceo, esbranquiçado; bractéolas 1-3, 0,5×0,2mm, triangulares, externamente recobertas por tricomas estrigoso-acinzentados; pedicelos 2-3mm compr., densamente recobertos por indumento tomentoso. Flores 3-5mm diâm.; sépalas 5, ca. 1,0×0,9mm, largo-ovais, ápice acuminado, externamente recobertas por indumento seríceo, internamente glabras ou pubescentes; pétalas 5 , 2,5-2,8×1,4-1,5mm, elípticas, oblongas, externamente recobertas por indumento seríceo, translúcido a acinzentado; estames 5 , ca. $1,5 \mathrm{~mm}$ compr., filetes ca. $1 \mathrm{~mm}$ compr., subulados, glabros, anteras $0,5-0,7 \mathrm{~mm}$ compr., cordiformes; disco anular, ca. 1,6mm diâm., 10-lobado, carpelos 5, conados, 2 óvulos por lóculo, recobertos por protuberâncias com indumento seríceo; estilete ca. $0,5 \mathrm{~mm}$ compr. acima do ovário, inserido entre os carpelos; estigma ca. $0,2 \mathrm{~mm}$ compr., capitado, levemente lobado. Cápsulas $2,3 \times 4,5 \mathrm{~cm}$ diâm. (Lima 12743), ovóides, lisas loculicidas e septicidas, com uma apófise obtusa nas pontas dos lóculos, ca. 0,4-0,5mm, pubérulas, tricomas hialinos, endocarpo com nervuras visíveis; semente $1,9,0 \times 7,8 \mathrm{~mm}$ compr. oval, base truncada, ápice obtuso, hilo linear.

Material examinado: BRASIL. Pernambuco: Paulista, X/1984, fl., Chiappeta 521(UFP).

Distingue-se das demais espécies por possuir folhas simples, glabras e flores densamente recobertas por indumento seríceo. Alguns espécimes provenientes de outros Estados apresentaram variação com relação ao tamanho da lâmina foliar.

No Brasil, ocorre nos Estados do Bahia, Espírito Santo, Mato Grosso, Pará, Pernambuco Rio de Janeiro e São Paulo.

2.5 Esenbeckia pilocarpoides Kunth, Nov. gen. Sp. 7: 192, t.655. 1825.

Fig. 65-67.

Árvores ou arbustos 2-5m alt. Ramos verdes a acinzentados, glabros. Folhas alternas, uni a bifolioladas; pecíolos 2,2-3,8mm compr., estreito-alados, planos ou canaliculados na face superior, base às vezes mais dilatada com fendas transversais, ápice com duas abas salientes ca. $1 \times 1 \mathrm{~mm}$, glabros a pubérulos; folíolos 8,0-16,5×3,4-5,8cm, sésseis, elípticos, obovados a elípticos, geralmente nas terminações dos ramos, base cuneada, ápice acuminado a levemente caudado, geralmente encurvado, margem revoluta, glabros, cartáceos, nervura central proeminente em ambas as faces. Panículas 4,5-12,2×2-3cm, terminais e axilares, pubescentes; bráctea 1, 1,0-1,2mm compr., oval com ápice acuminado, côncava, ciliada; bractéolas 2-3, 1,0-1,2mm compr., ovais com ápice acuminado, membranáceas, pubescentes e ciliadas. Flores 5-9mm diâm.; sépalas 5, 1,5-2,4mm compr., largo-ovais, ápice obtuso a arredondado, ciliadas, glandulares em ambas as faces; pétalas 5, 2,8-4,0×3mm, elípticas, obovais, 


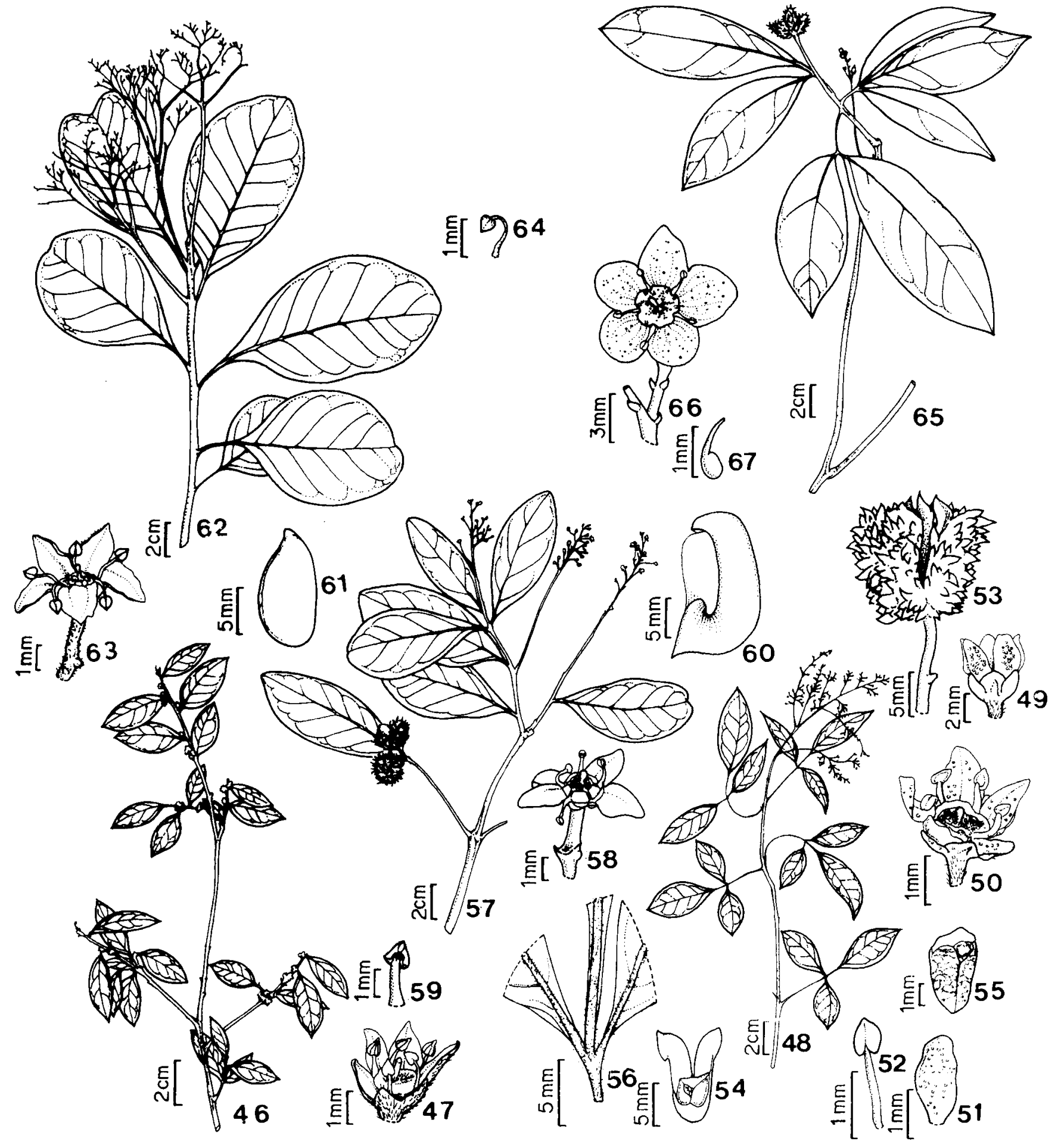

Figuras 46-47. Esenbeckia almawillia. 46. Hábito. 47. Flor (Andrade-Lima \& Magalhães 1070). Figuras 48-56. Esenbeckia febrifuga. 48. Hábito (Kuhn 46). 49. Botão (Muniz 328). 50. Flor. 51. Detalhe da pétala. 52. Estame. 53. Fruto (Catharino 1200). 54. Endocarpo com semente (Chiea 668 et al.). 55. Detalhe da semente (Catharino 1200). 56. Detalhe da face inferior dos folíolos (Kuhn 46). Figuras 57-61. Esenbeckia grandiflora. 57. Hábito (Guedes et al. s.n., ALCB 37117). 58. Flor (Carvalho et al. s.n., CEPEC 19137). 59. Antera cuculada (Tamashiro et al. 4596). 60. Detalhe do endocarpo com semente. 61. Semente (Attié et al. 133). Figuras 62-64. Esenbeckia leiocarpa. 62. Hábito. 63. Flor. 64. Estame (Thomas et al. 11021). Figuras 65-67. Esenbeckia pilocarpoides. 65. Hábito (Andrade-Lima 42). 66. Flor. 67. Detalhe do filete com base dilatada (Andrade-Lima 68-5266). 
ovais, mais ou menos transparentes, denso-glandulares, margem ondulada, ciliada, membranáceas, amareloclaras; filetes 0,6-1,4mm compr., subulados com base dilatada, glabros, anteras 0,6-0,9×0,5-0,6mm, cordiformes, ápice mucronado, recobertas por pequenas papilas inconspícuas; disco 2,0-2,4mm diâm., 5-lobado, anular, sulcado entre os lobos, glandular, pubérulo; carpelos depresso-globosos, adnados ao disco, recobertos por protuberâncias, 1-3mm compr., ovóides a piramidais, cercadas por tricomas estrigosos, estilete com 1,0-1,5mm compr., espesso, glabro, estigma, $0,2 \times 0,2 \mathrm{~mm}$, capitado, levemente lobado. Cápsulas $16 \times 27 \mathrm{~mm}$, depresso-globosas, superfície esparso-muricada, com apófises pontiagudas nas terminações dos lóculos, deiscência septicida e loculicida; semente 1 , ca. 9,2mm compr., oval, 1 por lóculo, ápice agudo, hilo linear, testa granulosa, castanho-escura.

Material examinado: BRASIL. Pernambuco: São Lourenço da Mata, VIII/1980, Andrade Lima \& Bocage 21 (IPA).

E. pilocarpoides pode ser reconhecida no campo pelo folíolo elíptico, com ápice acuminado ou levemente caudado.

Kaastra (1982) reconheceu duas subespécies: E. pilocarpoides subsp. pilocarpoides, de maior distribuição, principalmente na Colômbia, Guiana, Suriname, Trindade, Tobago e Venezuela. No Brasil está distribuída nos Estados do Pará, Mato Grosso e Pernambuco. E. pilocarpoides subsp. maurioides (Mart.) Kaastra é uma subespécie de distribuição mais restrita, ocorrendo no Maranhão e ao longo da costa da Bahia até o Espírito Santo. A subespécie típica diferencia-se de E. pilocarpoides subsp. maurioides pelas folhas unifolioladas, o ápice dos folíolos com cerca de $4-15 \mathrm{~mm}$ compr. e pecíolo estreito-alado, apresentando no ápice duas alas com 1-2mm larg. Em Pernambuco, o espécime pertence a $E$. pilocarpoides subsp. pilocarpoides. Vale salientar que as alas localizadas no ápice do pecíolo podem estar ausentes, como foi observado por Pirani (1999), coletando materiais recentes do sudoeste de Minas Gerais e noroeste de São Paulo.

No Brasil, esta espécie está distribuída nos Estados de Alagoas, Ceará, Mato Grosso e Pernambuco.

\section{Agradecimentos}

As autoras agradecem aos curadores dos herbários nacionais pelo envio, empréstimo e doações do material estudado; ao Dr. José Rubens Pirani, pela concessão de parte de sua tese de Livre Docência e pela confirmação das espécies estudadas do gênero Zanthoxylum; ao CNPq, pelo suporte financeiro com a bolsa de estudo para a primeira Autora.

\section{Referências bibliográficas}

Albuquerque, B. W. P. 1976. Revisão taxonômica das Rutácea do Estado do Amazonas. Acta Amazônica 6(3): 5-65.

Andrade-Lima, 1960. Estudos Fitogeográficos de Pernambuco. Arquivos do Instituto de Agricultura Indústria e Comércio - IPA. Boletim Técnico n. 8, Pernambuco.

Barroso, G. M.; Guimarães, E. F.; Ichaso, C. L. F; Costa, C. G.; Peixoto, A. L. \& Lima, H. C. 1986. Sistemática de Angiospermas do Brasil. v.2. Imprensa Universitária, Universidade Federal de Viçosa, Viçosa.

Bentham, G. \& Hooker, J. D. 1862. Genera Plantarum. vol.1., L. Reeve \& Co., London.

Beurton, C. 1994. Gynoecium and perianth in Zanthoxylum s. 1. (Rutaceae). Plant Systematics and Evolution 189: 165-191.

Brizicky, G. K. 1962. The genera of Rutaceae in the Southeastern United States. Journal of the Arnold Arboretum 43(1): 2-23.

Brummit, R. K. \& Powell, C. E. 1992. Authors of plant names. Royal Botanic Gardens, Kew.

Cowan, R. S. 1960. Rutaceae of Santa Catarina. Sellowia 12: 79-98.

Cowan, R. S. \& Smith, B. L. 1973. Rutaceae. Pp.70-98. In: R. Reitz (ed.). Flora Ilustrada Catarinense. Herbário Barbosa Rodrigues, Itajaí.

Engler, A. 1874. Rutaceae. Pp.12(2): 77-194. In: C. F. P. Martius \& H.G. Eichler (eds.). Flora Brasiliensis, Monachii, Frid. Fleischer.

Engler, H. G. A. 1931. Rutaceae. Pp.187-359. In: H. G. A. Engler \& K. Prantl (eds.). Die Naturlichen Pflanzenfamilien. vol. 19a, 2 ed., Wilhelm Engelmann, Leipzig.

Escalante, M. G. 1961. El género Fagara en la Argentina. Boletin de la Sociedade Argentina de Botanica 9: 291-317.

Ferraz, E. M. N.; Rodal. M. J. N.; Sampaio. E. V. F. B. \& Pereira, R. C. A. 1998. Composição florística em trechos de vegetação de caatinga e brejo de altitude na região do Vale do Pajeú, Pernambuco. Revista Brasileira de Botânica 21(1): 7-15.

Fish, F. \& Watterman. G. 1973. Chemosystematics in the Rutaceae II. The chemosystematics of the Zanthoxylum/ Fagara complex. Taxon 22(2/3): 177-203.

Guerra, M. S. 1987. Cytogenetics of Rutaceae IV. Structure and systematic significance of interphase nuclei. Cytologia 52: 213-222.

Hartley, T. G. 1966. A revision of the Malesian species of Zanthoxylum (Rutaceae). Journal of the Arnold Arboretum 47(3): 172-219.

Hickey, L. J. 1973. Classification of the architecture of dicotyledonous leaves. American Journal of Botany 1(60): 17-33. 
Holmgren, P. K.; Holmgren, N. H. \& Barnet, L. C. 1990. Index Herbariorum, Part. 1: the Herbaria of the World. 8. Ed. Botanical Garden, New York.

Kaastra, R. C. 1982. Pilocarpinae (Rutaceae). Pp. 471-488. In: Flora Neotropica Monograp 33. New York Botanical Garden, New York.

Lawrence, G. H. M. 1951. Taxonomia das plantas vasculares 2. Fundação Calouste Gulbenkian, Lisboa.

Lorenzi, H. 1992. Árvores brasileiras. Manual de identificação e cultivo de plantas arbóreas. Nova Odessa, São Paulo.

Pirani. J. R. 1999. Revisão de Helietta e Balfourodendron (Pteleinae). Análise cladística de Pteleinae. Sinopse de Rutaceae do Brasil. Tese de Livre Docência. Universidade de São Paulo, São Paulo.

Porter, D. M. \& Elias, T. S. 1979. Flora of the Panama: Rutaceae. Annals of Missouri Botanical Garden 66: 123-164.

Radford. A. E.; Dickinson, W. C; Massey, J. R. \& Bell, C. R. 1974. Vascular plant systematics. Harper \& Row Publishers, New York.
Record, J. S. \& Hess, R. W. 1940. American woods of the family Rutaceae. Tropical Woods 64: 2-28.

Reeder, J. R. \& Cheo, S. Y. 1951. Notes on Xanthoxylum and Fagara in China. Journal of the Arnold Arboretum 32: 67-72.

Sales, M. F.; Mayo, J. S. \& Rodal, M. J. N. 1998. Plantas vasculares das florestas serranas de Pernambuco. Imprensa Universitária, Pernambuco.

Spichiger, R. \& Ortega , L. S. 1987. Rutaceae. In: R. Spichiger (ed.). Flora del Paraguay. Conservatoire et Jardim Botanique de Gèneve, Gèneve.

Tavares, M. C. G.; Rodal, M. J. N.; Melo, A. L. \& Lucena, M. F. A. 2000. Fitossociologia do componente arbóreo de um trecho de floresta serrana do Parque Ecológico João Vasconcelos Sobrinho, Caruaru, Pernambuco. Naturalia 25: 243-270.

Tiffney. B. H. 1980. Fruits and seeds of the Brandon Lignite, V. Rutaceae. Journal Arnold Arboretum 1(61): 1-35.

Watterman, P. G. 1975. New Combination in Zanthoxylum L. Taxon 24 (2/3): 361-366.

Wilson, P. 1911. Rutaceae. North American Flora 3(25): 173-224. 